\title{
Partners and plagiarisers: Dualities in consultants' influence on organisational change projects
}

\section{David Shaw, University of Greenwich Business School}

\section{Abstract}

Purpose: This paper examines the interplay between the requirements for successful organisational change and the imperatives faced by management consultancy firms in running successful businesses, and how this interplay affects the ways in which management consultants influence organisational change projects.

Approach: The paper reviews literature on management consultancy and organisational change over the past 30 years to identify insights into this issue.

Findings: The paper shows that business imperatives faced by management consultancy firms affect the ways in which consultants influence organisational change projects. It shows how management consultants aspire to form strategic partnerships with their clients in order to win profitable business, and to plagiarise established organising practices and change management methods in defining their services in order to manage their costs. It illustrates how these aspirations give rise to a number of dualities that consultants face in undertaking organisational change projects.

Value: Only limited research has been carried out into the ways in which the business imperatives of management consultancy firms interact with the requirements for successful organisational change in shaping the influence that management consultants have on organisational change projects. This article demonstrates the significance of this issue and suggests directions for future research into it.

Keywords

Management consultants; organisational change projects; partnership; plagiarism; dualities; organisational politics.

\section{Introduction}

Management consultants have a major influence on how managers lead organisational change projects, but the value of their contribution remains a subject of debate (Fincham, 1999; Greiner and Ennsfellner, 2010; Sturdy, 1997). Nikolova and Devinney (2012) contrast the functionalist perspective, that consultants provide real help either through their specialised knowledge or their ability to facilitate joint learning with their clients, with the critical perspective, that consultants rather create the impression that their services have value through advocacy of ephemeral management fashions. Irrespective of the perspective adopted, there can be no doubt that management consultancy is a business with its own particular management requirements (Kipping and Clark, 2012). This paper draws upon a review of the management consultancy literature, alongside insights from the organisational change management literature (Al-Haddad and Kotnour, 2015; By et al., 2016), to assess how the interplay between the business imperatives of consultancy firms and the requirements for successful organisational change affect the ways in which consultants influence organisational change projects.

In his influential work on the management of professional service firms, Maister (1993) highlights two particular business imperatives that all professional service - including management consultancy - 
firms face. First, they have to establish strong relationships with their senior management clients, with a view to becoming established as their trusted business partners. This is important both in winning the large-scale, strategic organisational change projects upon which their revenue and reputation depend, and in securing repeat business with individual clients in the face of competition from rival firms. Repeat business is vital in enabling consultancy firms to avoid the additional marketing and service delivery costs involved in winning and carrying out work with new clients (Kitay and Wright, 2004). Second, Maister (1993) says that professional service firms have to manage their costs through leverage, that is, providing their services through an acceptably high ratio of more junior, lower cost staff to more senior, higher cost staff. In order to achieve these economic benefits, consultancy firms have to routinise their services sufficiently to enable them to train junior staff in how to provide them with limited supervision (Saam, 2012). The amount of leverage that is feasible depends on the business model of the individual consultancy firm (Morris et al., 2012), but as O'Mahoney and Markham (2013, p. 234) observe, 'leverage ... is central to most aspects of running a consultancy firm'. Hansen et al. (1999) indicate that a consultancy firm may operate with a ratio of only one Partner to as many as 30 less senior consultants, and these authors associate the commercial success of leading consultancy firms' business process reengineering services during the 1990s with their success in routinising their methods so as to achieve a high degree of leverage. Andersen Consulting (subsequently Accenture) trained their consultants to be 'implementers' of established ways of doing things, not to be 'inventors' of new ways of doing them, thereby facilitating a highly leveraged business model (Hansen et al., 1999, p. 110). While there is a plethora of literature on client-consultant relationships, and on aspects of the management of consultancy firms that affect their ability to achieve leverage, little has been written specifically about how the business imperatives that management consultants face may affect the ways in which they influence organisational change projects.

On a post-bureaucratic view, consultants' aspirations to be seen as trusted partners of their clients are legitimate and even laudable although, on a bureaucratic view, consultants are external contractors who should be held at arm's length and limited to the role specified for them by their designated client (Bäcklund and Werr, 2008). Clients tend to perceive the value of consultants as lying in their ability to facilitate innovation through services tailored to their particular organisations' unique circumstances (Clegg et al., 2004), so reusing standardised knowledge in these circumstances is unlikely to be regarded as laudable, or even perhaps legitimate. Wright et al. (2012) find that consultants downplay their reuse of standardised knowledge, while emphasising rather the innovative or even mould-breaking characteristics of their work. Endeavours to achieve the economic benefits of leverage may be associated with what Martin (1994) defines as institutionalised plagiarism. This form of plagiarism, of which senior managers delivering speeches as if they were their own thoughts when in fact they have been written for them by their junior staff is a typical example, is a widely accepted practice that attracts no opprobrium. Yet proactive declaration that a speech or a consultancy project is the product of institutionalised plagiarism might devalue it in the minds of its audience or clients.

This paper considers these two main themes, consultants' aspirations to be seen as partners of their senior management clients, and consultants' use of institutionalised plagiarism to attain the most economically favourable degree of leverage, through the lens of dualities management. Each of these two aspirations gives rise to tensions that reflect both the extent to which client-consultant relationships leave scope for opportunistic behaviour by consultants, and the opposing norms arising from the functionalist and critical perspectives on consultancy. In her discussion of paradox in the work of consultants, Whittle (2006) identifies a range of apparently opposed roles that management consultants perform that are closely connected with these themes. These include consultants' personas as business-hungry salespeople and disinterested, independent-minded professionals, and as proponents of standardised solutions and facilitators of organisational change programmes that 
are tailored to match their clients' distinct cultural contexts. In their account of the contribution of duality theory to organisational change, Sutherland and Smith (2013, p.220) say that 'duality theory specifies that complementarities exist within contradiction and their synergistic co-existence ensures that the qualities of both dimensions ... are recognised and exploited'. This paper explores various dualities that consultants face, which arise from the interaction between the business imperatives that they must address and the requirements for successful facilitation of organisational change.

A growing body of literature on management consultancy, as the consulting industry has been increasing in size and changing in character over the past 30 years, has created opportunities for scholars to develop new conceptual frameworks and ways of understanding consultancy through a number of studies that draw upon reviews of that literature (Alvesson, 2000; Clegg et al., 2004; Sturdy, 2011; Sturdy et al., 2009). The current study aims to make a contribution to this body of conceptual papers by considering theory and research on the themes of organisational change consultants' relationships with their senior management clients, and of their approach to achieving the economic benefits of leverage. It is based on review of 61 selected research papers that have been published since 1990. These papers were obtained through well-known digital and publishing resources, that is, Google Scholar, Emerald, JSTOR, Science Direct and Wiley Online Library. Only research papers in English have been included. Research papers of various types have been reviewed, including research based on interviews with consultants and/or their clients (22), conceptual papers and literature reviews (17), case studies (15), questionnaire surveys (6) and document review (1). Some of the papers that analysed interview data also included the results of other research methods, such as document review, observation and questionnaire survey. In order to limit the number of research papers to be reviewed to a manageable number, research papers in which there is only limited discussion of consultancy specifically in the field of organisational change or change management, for example where the primary focus is on systems integration, have been excluded.

The paper examines two aspects of each of the two themes outlined above. It discusses the aspirations of consultants to be partners of their senior management clients, first by playing a part in shaping the client organisation's change leadership team, and second by helping senior managers in the client organisation to gain acceptance of their ideas for change. The paper then discusses the aspirations of consultants to obtain the economic benefits of leverage, first by engaging in institutionalised plagiarism of established industry practices in defining the content of change, and second by engaging in institutionalised plagiarism of established change management methods in facilitating the process of change. Finally, the paper draws some conclusions about how the business imperatives facing consultants affect the ways in which they influence organisational change projects and suggests directions for future research that could confirm and extend our understanding of the issues.

\section{Partnering with clients to shape their change leadership team}

Drawing on Burns' (1978) work on leadership, Burke and Litwin (1992) characterise leadership as the central, transformational factor in managing an organisation's response to its environment. Burke and Litwin initially developed their model of organisational change through reflection on their own management consultancy experience, justifying it subsequently by reference to academic theory and empirical evidence, so their model reflects consultants' perceptions of the centrality of leadership as well as academic theorising. The senior managers leading an organisational change project will inevitably be the clients of the management consultants who are appointed to assist with it (Schein, 1997). Thus, identifying the clients for an organisational change project, and any roles of consultants in doing so, is a central issue. The scope and heterogeneity of the client group for management consultancy services in a large corporation can mean that identifying who the clients are can be an ambiguous and complex process. Schein (1997, pp. 202-203) identifies a range of different categories 
of client, including the initial 'contact clients', 'intermediate clients' who are subsequently involved, 'primary clients' who are responsible for solving the problem at issue, 'unwitting clients' who may be affected by the project but are not aware of it, 'indirect clients' who know they will be affected but are not known to the consultants, and 'ultimate clients' who have interests as stakeholders. Alvesson et al. (2009) point out that a variety of different people may perform client roles during the lifetime of a long-running project; that managers who are opposed to an organisational change project and may be adversely affected by it might be regarded as among the ultimate clients; and that coalitions may be formed among client groups in the organisation, with different coalitions engaging in political conflict with each other.

The diversity of, and potentially conflictual relationships among, clients give rise to the scope - and potentially the necessity - for consultants to engage in what Alvesson et al. (2009, p.258) describe as 'creating and constructing' the client group in order to go about their business. Alvesson et al. (2009) give an example of consultants facilitating a process among a group of change leaders, who hitherto had failed to give clear direction on the change to be implemented, to enable them to form a cohesive, decision-making group, and another where a consultant sought to influence the membership of an organisation's client group by introducing a new manager into it, thereby on that occasion provoking a sense of betrayal in the mind of an established client. Sturdy (1997) says that resolving conflicts among members of the client organisation can be a key consultancy role. In their account of the practices of developing strategy and managing organisational change, Whittington et al. (2006) describe how consultants facilitated a carefully orchestrated stakeholder consultation process within a voluntary sector organisation, whereby a decision that the chief executive had already made was able to emerge as the outcome of the consultation process, while other members of the client group who might have opposed the decision were sidelined.

Consultants seek strong relationships as business partners of clients (Werr and Pemer, 2007), and their ability to help shape the change leadership team clearly depends on achieving such relationships. Glückler and Ambrüster (2003) argue that 'experience-based trust' is a key source of competitive advantage for consultancy firms, because it is the foundation for enduring relationships with clients that generate repeat business, together with 'networked reputation', whereby satisfied clients may refer other potential clients who trust them to a consultancy firm that has done successful work for them in the past. Because of the difficulties involved in making objective assessments of the quality of consultancy services, establishment of a relationship of trust is widely seen as a primary means whereby consultancy firms can achieve the strategic partnerships with their clients that they seek (Furusten, 2013; Kalali and Heiden, 2016; Lalonde and Gilbert, 2016; Nikolova et al., 2015; Solomonson, 2012). Through a survey of management consultants in Germany, Bronnenmayer and Wirtz (2016) find that trust appears not to be a significant factor in the perceived success of consultancy projects, for example in terms of whether or not a consultancy project leads to repeat business. These authors suggest, however, that this is not because trust is not valuable in building a successful client relationship, but because employees of client organisations tend to approach consultancy projects with a negative image of management consultants, which cannot easily be overcome during the typically limited timescale of the projects. Distrust of management consultants is widespread for a variety of reasons. There are no generally recognised professional standards for management consultancy (Glückler and Ambrüster, 2003; Harvey et al., 2017). In their case study of the change management firm, 'Valley Consulting', Morris and Empson (1998, p.619) quote a consultant as saying: 'There is a kind of magic to what we do with our clients. I can't really describe it to you. I certainly can't write it down on a piece of paper.' Services as mysterious as this are clearly beyond the reach of any objective standards of evaluation. Clients often perceive consultants as being arrogant, paid too much, and excessively focused on making money (Bronnenmayer and Wirtz, 2016; 
Retna, 2015). It is understandable for the generality of employees of a client organisation to distrust management consultants, particularly as consultants are likely to be more mindful of the interests of the senior managers who appoint them than of the generality of employees (Huszczo and Sheahan, 1999). It is difficult for consultants to establish the degree of trust that is needed to form the foundation for a strategic partnership with a client, but it is the trust of those senior managers who can form a dominant coalition in an organisation, and not that of the generality of its employees, which they need to form a successful business relationship.

In addition to the intrinsic difficulties for management consultants in establishing the necessary trust on which to base a strategic partnership, Alvesson et al. (2009) highlight models of management consultancy under which a relationship involving this level of influence would be regarded as illegitimate, the legitimate role of consultants being rather that of ancillary workers carrying out the instructions of a designated client. Similarly, Bäcklund and Werr (2008) contrast a post-bureaucratic view, whereby consultants might be seen as partners of their clients, co-producing solutions to problems with them, with a bureaucratic perspective, whereby consultants would be limited to roles as knowledgeable outsiders keeping to the brief set for them by a designated client. Managers in a client organisation may indeed feel at liberty to treat consultants as subservient assistants rather than as partners, imposing long hours of work and other pressures on them that they would not expect their own employees to accept (Alvesson and Kärreman, 2004; Alvesson and Robertson, 2006; Kitay and Wright, 2004). Moreover, competition among consultancy firms and questioning of consultants' claims to specialist expertise can tend to undermine an individual firm's attempts to gain influence at the strategic apex of an organisation (Fincham, 1999; Greiner and Ennsfeller, 2010; Nikolova et al., 2009).

Consultants have to manage a duality that involves, at one polarity (Seo et al., 2004), seeking to be the client's strategic partner while, at the other polarity, when a strategic partnership is not a realistic aspiration, accepting the role of an external contractor performing what Burke and Litwin (1992) describe as a transactional, or operational, role. Seo et al. (2004) identify separation as a way of managing dualities, for example by operating at one polarity in some circumstances or at certain times and operating at the other polarity in other circumstances and times. Thus, separation may involve seeking to exert influence as strategic partners with some clients, shaping the membership and ways of working of the change leadership team, where client relationships are strong enough for this to be possible, while accepting more limited, operational roles with others where they are not. Separation may also involve embracing different polarities with the same client at different points in time, for example by beginning to form a client relationship by carrying out a limited, operational project, while working towards a stronger relationship whereby they could ultimately achieve a strategic partnership. As Gill and Whittle (1993) suggest, consultants face a typical lifecycle whereby managers' initial enthusiasm for particular ideas and the consultants who promote them eventually gives way to disillusionment, potentially leading to the requirement to replace established clients who are approaching the end of that lifecycle with new ones. Confinement to serial sales of transactional projects with different clients, however, would typically undermine the ability of a large consultancy firm to achieve its business strategy. The concept of transformational leadership, on which Burke and Litwin (1992) base their model, assumes a hierarchical relationship between leaders and followers. Achievement of organisational change, however, often depends upon representational leadership, that is, leadership that exerts influence on peers and colleagues rather than subordinates (Pettigrew and Whipp, 1991), and in these circumstances the political complexity of organisational change comes to the fore. These aspects are considered in the next section. 
Partnering with clients to gain acceptance of ideas for change

In order for managers to accept consultants as their strategic partners, they need to be convinced that they are 'on their side', both when those managers engage in the politics of pursuing their organisations' business objectives, and potentially also when they engage in the politics that affect their personal ambitions and careers. Organisational change is a political process, involving the legitimisation of new ideas and the delegitimisation of old ones (Pettigrew, 2012). Kotter (1995, p.61) recommends 'forming a powerful coalition' as a key step in accumulating the necessary political power in an organisation to drive forward change. Consultants may be active in identifying the dominant influencers in a client organisation, and in engaging in political struggles in support of those influencers' agenda for change (Glückler and Ambrüster, 2003). Managers for their part may make use of consultants to assist them in legitimising their own ideas among their colleagues while delegitimising others, and they may engage in opposing coalitions of clients and consultants, each pursuing their own organisational objectives (Alvesson et al., 2009; Sturdy et al., 2009). Clients may expect their consultants to help them to form a favourable impression of themselves in the minds of their colleagues in internal events (Nikolova et al., 2015). Werr and Styhre (2003) observe that managers sometimes face tensions between using consultants to help advance their own careers and using them to achieve wider objectives for the benefit of their organisations. Whether managers like particular consultants, and their personal chemistry with them, influences their willingness to give them repeat business, and liking and personal chemistry may be affected by the consultants' willingness to support their personal agenda (Chelliah and Davis, 2010; Nikolova et al., 2015).

Beckhard and Harris (1987) recommend that organisation development practitioners should make systematic 'maps' of the readiness for change, and the capability to bring about change, of key stakeholders in an organisation. Sturdy et al. (2009) observe that management consultants make use of such 'mapping' techniques as a means of monitoring the level of support for a planned change among stakeholder groups - a key means of directing and monitoring the effectiveness of their political advocacy. Reflecting on his own consultancy practice, Schein $(1997$, p. 213) says that he may 'help a manager to win a political battle over another manager', albeit only if he judges that doing so will be for the good of the ultimate clients. Consultants who may be dependent on few clients, or even a single client, face pressures to adapt their services to the expectations of particular managers who can influence how much business they are awarded (Czarniawska and Mazza, 2003). The continuing tendency for consultancy services to be procured through relationships between particular senior managers and consultants, rather than through rational, criterion-based procurement processes whereby an organisation's purchasing function mediates between its senior managers and their consultants, enlarges the scope for opportunistic behaviour by consultants in responding to the commercial pressures that they face (Kitay and Wright, 2004; Werr and Pemer, 2007). The absence of professional standards that are universally adopted among consulting firms (Glückler and Ambrüster, 2003; Harvey et al., 2017), together with successful resistance to attempts to regulate the management consultancy industry (Kirkpatrick et al. 2012), increases the potential for commercial interests to be balanced against, or indeed predominate over, the independent-mindedness that might be expected of practitioners of an established profession. For example, Greiner and Ennsfellner (2010) record a claim that simply being recruited by McKinsey \& Co. is sufficient to confer professional status on a consultant, while Furusten (2013) argues that management consultancy is a modern form of profession whereby the claim to professional status depends largely on market acceptance. Sturdy et al. (2006) point out that the ability of management consultants to engage with client managers in liminal spaces, such as business dinners, adds to the scope for consultants to engage in political action, for example by consulting with some managers in these informal settings but not with others, thereby disfranchising them. 
At the same time, under the bureaucratic perspective on consultancy (Bäcklund and Werr, 2008), such partisanship would be wholly illegitimate, and some writers emphasise the role of consultants as disinterested professionals, adhering to high standards of independent-mindedness and integrity, or at least needing to do so in order to earn and deserve the trust of clients (Ben-Gal and Tzafrir, 2011; Greiner and Ennsfellner, 2010). Lalonde and Gilbert (2016) point out that, while there may be scope for consultants to use their skills in building trust among their clients in a manipulative way, the fact that they set out to create a particular impression in the minds of their clients need not mean that their actions are misleading or self-serving. Moreover, where consultants have been unable to establish the necessary personal chemistry and liking within a client organisation, such a role would anyway be unachievable (Chelliah and Davis, 2010; Nikolova, 2015). Consultants therefore have to manage a second duality, involving at one polarity helping their clients to win political battles with their colleagues, and at the other standing aside from political processes as independent professionals. Seo et al. (2004) identify integration as a method of managing such a duality, that is, striking a compromise between the two polarities, for example by engaging in their clients' political processes to a limited extent by providing objective evidence to help legitimise their clients' proposals for change, but in other respects maintaining a stance of objectivity and independence. The approach consultants take will be affected by the extent to which their clients accept them as strategic partners, and their clients' expectations of that partnership. A key way in which the client-consultant relationship affects the approach taken towards organisational change is the client's appetite for innovation and the consultant's response to it. This aspect is discussed in the next two sections.

\section{Plagiarising established industry practices in defining the content of change}

Achtenhagen et al. (2003) point out that one measure of organisational innovation is the extent to which ideas that are being implemented are novel within a particular organisation, so consultants who plagiarise the ideas of other participants in their client's industry, rather than introducing ideas that break wholly new ground, may still be helping their client to innovate. An organisational change project that is focused on alignment with established 'best practice', therefore, may well satisfy the client's appetite for innovation at the same time as it facilitates leverage for the consultancy firm, by allowing scope for reuse of the industry knowledge that the firm has collected and stored in its knowledge management systems (Hansen et al., 1999).

Clegg et al. (2004) present a model of management consultancy as an activity that facilitates organisational innovation by disrupting the status quo. In this model, the management theory to which consultants are presumed to be privy is used to disturb established ways of doing things. Werr and Styhre (2003) suggest that the introduction of management consultants into an organisation can alter its context in such a way as to inject new energy for change. Retna (2015) and Sturdy et al. (2009) point out that consultants may introduce new knowledge into the client organisation that challenges established ways of thinking as a result of their status as outsiders. Much of the influence of management consultants stems from their status as neither insiders of the client organisation nor yet complete outsiders to it, but as in-between actors who occupy liminal spaces in which the usual conventions of business life do not apply and innovative thinking can be facilitated (Czarniawska and Mazza, 2003; Sturdy et al., 2006). Kitay and Wright (2004) and Sturdy et al. (2009) observe that project teams, including joint client-consultant project teams, can provide such liminal spaces, in which the normal ways of doing business may give way to radical new thinking.

Wright et al. (2012) find that consultants themselves embrace the view that they help clients implement radical, disruptive innovation, but they question how far this discourse represents the reality of consultancy work. In fact, much of the content of organisational change that consultants advance is based on established knowledge of industry 'best practice' (Sturdy, 1997; Wright et al., 
2012). Moreover, radically innovative ideas often meet with resistance within consultancy firms because of their incompatibility with the firm's existing ways of thinking and acting (Heusinkveld and Benders, 2012). Wright et al. (2012) give an example of a consultancy project in which the role of the consultants was to achieve a 'vanilla' implementation of an enterprise resource planning system, that is, adapting the organisation's business processes to those deemed to be 'best practice' by the designers of the system. Variations from these externally established 'best practices' to accommodate the organisation's distinctive needs, as perceived by its employees, had to be minimised in order to achieve that 'vanilla' implementation. In contrast with the view of Lalonde and Gilbert (2016, p.632), that consultants' actions in creating impressions in the minds of their clients may be simply 'the expression of self ... as a reflective practitioner', Clark and Salaman (1998) suggest that consultants create illusions in the minds of their clients to sustain their impressions of the value of the consultancy services provided, which may extend to illusions as to how innovative they really are. Indeed, these writers argue that managing their clients' impressions lies at the heart of consultancy work. Drawing on the theatrical metaphor that these writers suggest, consultants may create the front-stage illusion that they are offering radically innovative services that they have designed specifically to meet the particular circumstances of their clients, while masking a back-stage reality that they have copied the substance of their services from standardised models of organising practices. Moreover, this may extend to consultants persuading clients to accept particular definitions of their problems that match routinised services that their firms have developed in the past (Clark and Salaman, 1998; Furusten, 2009). A key feature of consultants' business is to find out about existing trends in organising practices, and then to package them for sale to their clients (Heusinkveld and Visscher, 2012; Wright et al., 2012). Wright et al. (2012) suggest that many of the benefits of consultancy projects stem from enterprisewide adoption of established 'good practices', associated with avoidance of the costs of divergent ways of doing business in a single organisation, rather than fundamental innovation.

Sturdy (1997) observes that managers face a tension between wishing to be innovative and independent-minded in addressing the uniqueness of their particular organisation and wishing to conform to accepted organisational thinking. A plagiarising approach by consultants, which combines a claim to be providing radical and innovative organisational transformation with reliance on a change agenda that has been drawn largely from known external 'best practices', may have some appeal to managers facing such a tension. Furusten (2009) argues that a successful relationship between a client and a consultant depends on both parties knowing what to expect of each other, with no surprises. As a consequence, consultants tend to improvise on expected themes when developing solutions for their clients (Furusten, 2009; Heusinkveld and Visscher, 2012). This improvisation, as in the case of a jazz musician, is a skilled process that introduces elements of variation, but maintains continuity with existing thinking rather than breaking wholly new ground. Truly mould-breaking innovation might meet with so much resistance from powerful clients as to be unimplementable (Sturdy, 1997; Sturdy et al., 2009; Wright et al., 2012). Thus, the literature suggests that consultants face a third duality, with one polarity involving copying or adapting externally established 'best practices', and another involving radical, disruptive innovation. An integrating approach to managing this duality (Seo et al., 2004), combining known 'best practices' with sufficient improvisation to meet clients' expectations of innovativeness, may enable consultancy firms to achieve the efficiency benefits of reuse of existing knowledge while still satisfying their clients. Just as consultants may benefit from plagiarising the content of their organisational change proposals, while maintaining a discourse of radical and disruptive change, comparable issues arise in relation to the processes through which they seek to facilitate organisational change. This issue is discussed in the next section. 
Plagiarising established methods in facilitating the process of change

If consultancy firms plagiarise standard change management methods and use step-by-step guidance and standard tools and techniques for addressing particular issues, which they have developed through previous projects, they can deploy less experienced, and therefore less costly, consultants than would otherwise be required (Heusinkveld and Visscher, 2012; O'Mahoney and Markham, 2013; Werr et al., 1997). Molloy and Whittington (2015) comment on consultancy practices in customising standard change management methods, so as to make them better adapted to clients' particular circumstances and more acceptable to them, including flexible adaptation of standard project management methods whose over-rigorous application can provoke resistance among clients. Management consultancy firms' knowledge management systems provide a repository of methods, tools and techniques that give ready access to standardised approaches to doing consultancy work, but the codified knowledge contained in these systems is complemented by the tacit, experiencebased knowledge of individual consultants (Hansen et al., 1999; Werr and Stjernberg, 2003). Werr and Stjernberg (2003) discuss a case study of the use of a knowledge management system by Ernst \& Young in Sweden. This system contains a large number of standard methods and tools for use by consultants, for example in undertaking business process reengineering projects. In addition to these overarching method documents the system holds a repository of individual cases of completed projects, which consultants may draw upon in adapting the detailed application of those methods to match particular client situations. Werr and Stjernberg (2003, p. 890) quote a consultant as saying that: 'I see the method more as a thought model, with certain recurring steps and basic building blocks one can learn. Once learned, you can build more freely with them'. Thus, consultancy firms' knowledge infrastructure provides consultants not only with access to standard methods, but also with resources that facilitate customisation of those methods to suit particular client situations and expectations. Van Nistelrooij et al. (2007) report that consultants predominantly perceive organisational change as coming about as a result of people's own learning and sense-making, implying a need for flexible, non-standard methods that draw upon the expertise of experienced consultants in order to match a client organisation's particular circumstances, but they find that consultants' predominant practice is actually to use traditional forms of intervention, drawing upon standardised project management methods, involving sequential processes of planning and implementation in approaching organisational change projects. Sturdy et al. (2009) observe that, while facilitating the learning of client staff may be a declared aim of a management consultancy project, consultants are liable to deprioritise this aim in response to pressures to complete project tasks within agreed timescales and budgets.

Leading change in large organisations is far too complex to be capable of reduction to a set of simple, sequential steps (By et al., 2016; Pettigrew, 2012). This is widely recognised by consultants themselves (Van Nistelrooij et al., 2007; Visscher, 2006). Nikolova et al. (2009) highlight the value of social learning as a particular model of management consultancy whereby problems are diagnosed and solved through collaborative working between consultants and client staff, so that joint project teams become a key vehicle for learning by client staff, and by consultants also. There are many factors that encourage the use of routinised change management methods, however, including in particular the economic benefits to consultancy firms of continual reuse of standard methods, albeit with such customisation as client expectations demand. Moreover, as Alvesson and Kärreman (2004) observe, consultants can be held to account for their achievement or otherwise of pre-specified, concrete steps in a consultancy project plan, such as whether or not an IT system works technically and is delivered on time, but they have considerable latitude in deciding the depth to which they will engage in the more uncertain organisation development activities that may be needed to ensure that users of the system have the skills and motivation to obtain the full business benefits from it. Thus, consultants 
face a fourth duality, with one polarity involving the capture of the efficiency benefits of plagiarising existing, routinised methods for managing organisational change, and the other involving greater recognition of the complexity of organisational change and the expectations of some clients for consultancy services designed specifically to address their particular circumstances. The observation of Molloy and Whittington (2005) that consultants are often skilled in customising standard change management methods suggests the possibility of an integrating approach to managing this duality, whereby consultants adapt their methods sufficiently to meet clients' expectations for change management processes that have been designed specifically to meet their individual needs, while still copying those processes to a large extent from routinised change management methods.

\section{Conclusion}

The literature from the past 30 years shows that consultants have substantial influence on organisational change projects. The extent to which - and the way in which - they exert influence, however, depends in part on the interaction between the requirements for successful organisational change and the business imperatives facing consultants, in particular those related to client relationship management and leverage. Clients will only accept consultants as strategic partners with a licence to influence the membership and ways of working of the change leadership team, and the political processes whereby some ideas affecting organisational change are legitimised and others delegitimised, in the presence of strong relationships between consultants and senior managers. Consultants will only accept contracts to support organisational change projects if the degree of leverage that they permit, based on the available opportunities for institutionalised plagiarism, is consistent with their business model and will produce acceptable financial returns.

Consultants have good reasons to seek client relationships that are strong enough to enable them to shape the membership and ways of working of change leadership teams in directions that are favourable towards their commercial interests. They also have good reasons to foster relationships with individual senior managers who are willing to commission work from them by supporting them in achieving their organisational and personal objectives. Success in forming such relationships is important in enabling consultants to secure repeat business with the same clients, thereby reducing the costs of both selling and of implementing consultancy projects. Consultants also have good reasons to take advantage of available opportunities to plagiarise both the organising practices that they recommend to their clients, and the change management methods that they use in implementing them, because by doing so they can obtain the maximum value from the knowledge that they have captured and stored from prior consultancy assignments and research. Moreover, a key sales technique in consultancy is to identify current organisational trends, and to package services designed to help their clients to replicate them, with a view to selling those same services multiple times to different clients. These incentives on consultancy firms inevitably have the potential to affect the ways in which consultants influence the organisational change projects in which they are involved.

The business models of consultancy firms, therefore, lead their consultants to aspire to strategic partnerships with their clients and leverage through plagiarising established knowledge of current organising practices and methods of managing organisational change. While a bureaucratic view of consultancy would lead managers to balk at consultants' aspirations for partnership with them, the widespread acceptance of a post-bureaucratic view serves to help legitimise this aspiration (Bäcklund and Werr, 2008). In order to secure their clients' acceptance of services that are often copied from established models of organising practices and routinised change management methods, however, consultants may seek to create the illusion that their services are more innovative and tailored to their clients' individual circumstances than they really are. In neither case can consultants be assured of realising their aspirations. Competition from rival firms and the scepticism of some clients makes 
achievement of a strategic partnership with a client a challenging mission, while the realities of effective organisational change management and the expectations of clients for innovation and individually tailored services are a barrier to simple reuse of standard recipes for organisational change. The interaction between client and consultant interests is therefore played out through a range of dualities that consultants must manage. The dualities to emerge from the above discussion are summarised in Table 1.

Table 1: Dualities that organisational change consultants manage

\begin{tabular}{|l|l|}
\hline Partnering with clients to shape their change leadership team \\
\hline $\begin{array}{l}\text { Shaping the change leadership team's } \\
\text { membership and ways of working }\end{array}$ & $\begin{array}{l}\text { Carrying out a designated client group's } \\
\text { instructions }\end{array}$ \\
\hline Partnering with clients to gain acceptance of ideas for change \\
\hline Engaging in the client's political processes & Providing independent, professional advice \\
\hline Plagiarising established industry practices in defining the content of change \\
\hline $\begin{array}{l}\text { Facilitating alignment with industry 'best } \\
\text { practice' }\end{array}$ & Facilitating mould-breaking innovation \\
\hline Plagiarising established methods in facilitating the process of change \\
\hline Reusing standard change management methods & $\begin{array}{l}\text { Tailoring methods to address the client's unique } \\
\text { circumstances }\end{array}$ \\
\hline
\end{tabular}

Only limited research has been carried out into the ways in which the interaction between the requirements for effective organisational change management and the business requirements of management consultancy firms affects the nature of consultancy services and their influence on organisational change projects. This paper suggests areas for such research, in particular into the ways in which that interaction plays out in the dualities highlighted in Table 1, which could shed light on how consultants influence organisational change projects in the contemporary business world and why they exert that influence as they do. A key aspect of this research could be the ways in which consultancy firms incentivise their employees to meet their business imperatives, and the organisational change management opportunities and constraints to which those incentives lead. The paper also suggests areas for research into how consultants might, at least to some extent, transcend the dualities involved in partnering with clients and plagiarising established organising practices and change management methods, that is, in order that 'dualities are transcended so that the original tension among them no longer exists' (Seo et al., 2004, p. 77).

Werr and Pemer (2007) draw attention to moves towards greater involvement of purchasing professionals in procuring management consultancy services, in the private as well as in the public sector. The challenges involved in appraising consultancy services in a structured, systematic way, and the inherently political character of organisational change, constrain the scope for purchasing professionals to exert influence on these decisions. Nevertheless, such moves might facilitate a shift in the basis for strategic relationships between consultants and their senior management clients towards more systematic selection criteria and away from subjective considerations of personal chemistry and liking that currently can play a decisive role (Chelliah and Davis, 2010). Professional procurement processes could help to transcend the dualities faced by some consultants - for example between offering to advance an influential client's personal agenda and limiting themselves to giving professional, independent-minded advice - by anchoring the decision to select a particular consultancy firm to objective, capability-related factors. Strong management consultancy firms could benefit from a shift in the basis of competition towards firms' functional capabilities and away from the vagaries of personal relationships between individual consultants and clients. Research into the 
ways in which purchasing professionals currently seek to introduce objective, criterion-based methods into decision-making about the appointment of consultants, and into the potential and limitations of those methods, could be valuable in identifying ways of transcending, at least to some extent, the dualities that consultants face in seeking partnerships with their clients.

Werr and Stjernberg (2003) illustrate the ways in which consultancy firms use their knowledge management systems to provide their consultants both with standard ways of carrying out consultancy projects and with information about individual projects that serve as resources to help them apply and adapt those methods in detail to the needs of particular clients. Wright et al. (2012) find that consultants tend to represent their contributions as being radical and innovative, when in reality much of what they offer is based on standard industry practices. This appears to reflect the insight of Clark and Salaman (1998) that impression management lies at the heart of consultancy work, and that the back-stage reality is often different from the front-stage impression. Yet Sturdy (1997) observes that, while clients may be drawn towards recipes for change that are innovative and tailored to the individual circumstances of their businesses, they also want to be seen to be in step with accepted organisational thinking. There may be a range of reasons why consultants engage in institutionalised plagiarism in the use that they make of their prior experience and research in their offerings to their clients, including the obligation to respect the confidentiality of information about how particular clients have in the past developed their organisations. Nevertheless, greater transparency with their clients as to the uses that consultants make of their firms' prior client experience - where appropriate keeping the identity of the client organisations involved confidential - could help consultants to transcend the dualities that they face between plagiarising established industry practices and change management methods on the one hand and facilitating mould-breaking innovation and applying individually tailored change management methods on the other. Werr et al. (1997) observe that reuse of routinised knowledge, by offering an efficient way of dealing with the more basic aspects of a consultancy project, can enable greater effort to be applied to more demanding aspects where innovative thinking is really required. By making explicit the case studies from their knowledge management systems upon which they are drawing in approaching a particular client's organisational change project, and the areas in which they are applying novel thinking that is individually tailored to that client's particular circumstances, consultants could give their clients both greater assurance where the solution proposed has been demonstrated to be practicable in other settings and a clearer appreciation of where their work is individually tailored and innovative. If the expectation were to be established that consultancy firms would expose the content of their knowledge management systems to examination by their clients in this way - both to substantiate the practicability and business benefits of their recommendations and to highlight areas of individually tailored support and genuinely radical innovation - firms that maintain knowledge management systems of high quality would derive even greater competitive advantage from them than is already the case. Research into how far and in what ways consultancy firms use client case studies from their knowledge management systems in this way, and how far clients value this information, could be beneficial in identifying ways of both strengthening the evidence base underlying consultancy interventions in organisational change projects and reducing consultants' reliance on impression management. 


\section{References}

Achtenhagen, L., Melin, L. and Müllern, T. (2003), "Learning and continuous change in innovating organisations", in Pettigrew, A.M., Whittington, R., Melin, L., Sánchez-Runde, C., Van Den Bosch, F. A. J., Ruigrok, W. and Numagami, T. (Eds.), Innovative forms of organising, London: Sage, pp. 72-94.

Al-Haddad, S. and Kotnour, T. (2015), "Integrating the organisational change literature: a model for successful change", Journal of Organisational Change Management, Vol. 28 No. 2, pp. 234-262.

Alvesson, M. (2000), "Social identity and the problem of loyalty in knowledge-intensive companies", Journal of Management Studies, Vol. 37 No. 8, pp.1101-1123.

Alvesson, M. and Kärreman, D. (2004), "Interfaces of control: Technocratic and socio-ideological control in a global management consultancy firm", Accounting, Organisations and Society, Vol. 29 No. 2-3, pp. 423-444.

Alvesson, M., Kärremand, D., Sturdy, A. and Handley, K. (2009), "Unpacking the client(s): Constructions, positions and client-consultant dynamics", Scandinavian Journal of Management, Vol. 25, pp. 253-263.

Alvesson, M. and Robertson, M. (2006), "The best and the brightest: the construction, significance and effects of elite identities in consulting firms", Organisation, Vol. 13 No. 2, pp. 195-224.

Bäcklund, J. and Werr, A (2008), "Constructing the legitimate buyer of management consulting services", Journal of Organisational Change Management, Vol. 21 No.6, pp. 758-772.

Beckhard, R. and Harris, R. T. (1987), Organisational transitions: Managing complex change (2nd ed.). Reading, MA, Addison-Wesley.

Ben-Gal, H. C. and Tzafrir, S.S. (2011), "Consultant-client relationship: one of the secrets to effective organisational change?", Journal of Organisational Change Management, Vol. 24 No. 5, pp. 662-679.

Bronnenmayer, M. and Wirtz, B.W. (2016), "Determinants of perceived success in management consulting: An empirical investigation", Management Research Review, Vol. 39 No. 6, pp. 707-738.

Burke, W.W. and Litwin, G. (1992), "A causal model of organisational performance and change", Journal of Management, Vol. 18 No. 3, pp. 523-545.

Burns, J.M., (1978), Leadership, New York: Harper Row.

By, R.T. (2005), "Organisational change management: A critical review", Journal of Change Management, Vol. 5 No. 4, pp. 369-380.

Chelliah, J. and Davis, D. (2010), "But do you like your (expensive management) consultant?", Journal of Business Strategy, Vol. 31 No. 2, pp. 34-42.

Clark, T. and Salaman, G. (1998), "Creating the 'right' impression: Towards a dramaturgy of management consultancy", The Services Industries Journal, Vol. 18 No.1, pp. 18-38.

Clegg, S.R., Kornberger, M. and Rhodes, C. (2004), "Noise, parasites and translation: Theory and practice in management consulting", Management Learning, Vol. 35 No. 1, pp. 31-44.

Czarniawska, B. and Mazza, C. (2003), “Consulting as a liminal space”, Human Relations, Vol. 56 No. 3, pp. 267-290. 
Fincham, R. (1999), "The consultant-client relationship: Critical perspectives on the management of organisational change", Journal of Management Studies, Vol. 36 No. 3, pp. 335-351.

Furusten, S. (2009), "Management consultants as improvising agents of stability", Scandinavian Journal of Management, Vol. 25 No. 3, pp. 264-274.

Furusten, S. (2013), "Commercialised professionalism on the field of management consulting", Journal of Organisational Change Management, Vol. 26 No.2, pp. 265-285.

Gill, J. and Whittle, S. (1993), "Management by panacea: accounting for transience", Journal of Management Studies, Vol. 30 No. 2, pp. 281-295.

Glückler, J. and Ambrüster, T. (2003), "Bridging uncertainty in management consulting: The mechanisms of trust and networked reputation”, Organisation Studies, Vol. 24 No. 2, pp. 269-297.

Greiner, L. and Ennsfellner, I. (2010), “Management consultants as professionals, or are they?" Organisational Dynamics, Vol. 39 No. 1, pp. 72-83.

Hansen, M.T., Nohria, N. and Tierney, T. (1999), "What's your strategy for managing knowledge", Harvard Business Review, Vol. 77 No. 2, pp. 106-116.

Harvey, W., Morris, T. and Müller Santos, M., (2017), "Reputation and identity conflict in management consulting", Human Relations, Vol. 70 No. 1, pp. 92-118.

Heusinkveld, S. and Benders, J. (2012), "Consultants and Organisation Concepts", in Kipping, M. and Clark, T. (Eds), The Oxford Handbook of Management Consulting, Oxford University Press, pp. 267284.

Heusinkveld, S. and Visscher, K. (2012), "Practise what you preach: How consultants frame management concepts as enacted practice", Scandinavian Journal of Management, Vol. 28 No. 4, pp. 285-297.

Huszczo, G. E., \& Sheahan, M. (1999), "The advocacy approach to OD consulting: Neutral is not enough", Leadership \& Organization Development Journal, Vol. 20 No. 5, pp. 262-268.

Kalali, N.S. and Heiden, A, (2016), "How was competitive advantage sustained in management consultancies during change: The role of dynamic capabilities", Journal of Organisational Change Management, Vol. 29 No. 5, pp. 661-685.

Kipping, M. and Clark, T. (2012), "Researching management consulting: An introduction to the handbook", in Kipping, M. and Clark, T. (Eds), The Oxford Handbook of Management Consulting, Oxford University Press, pp. 1-26.

Kirkpatrick, I. Muzio, D. and Ackroyd, S. (2012), "Professions and Professionalism in Management Consulting", in Kipping, M. and Clark, T. (Eds), The Oxford Handbook of Management Consulting, Oxford University Press, pp. 187-206.

Kitay, J. and Wright, C. (2004), "Take the money and run? Organisational boundaries and consultants' roles", The Services Industries Journal, Vol. 24 No. 3, pp. 1-18.

Kotter, J. P. (1995), "Leading change: Why transformation efforts fail", Harvard Business Review, Vol. 73 No. 2, pp. 44-56.

Lalonde, C. and Gilbert, M., (2016), "Dramaturgical awareness of consultants through the rhetoric and rituals of cooperation", Journal of Organisational Change Management, Vol. 29 No. 4, pp. 630-656. 
Maister, D.H. (1993), Managing the professional service firm, New York: Free Press.

Martin, B. (1994), "Plagiarism: A misplaced emphasis", Journal of Information Ethics, Vol. 3, No. 2, pp. 36-47.

Molloy, E. and Whittington, R. (2005), "Practices of organising: Inside and outside the processes of change", Strategy Process, Vol. 22, pp. 491-515.

Morris, T. and Empson, L. (1998), "Organisation and expertise: An exploration of knowledge bases and the management of accounting and consulting firms", Accounting, Organisations and Society, Vol. 23 No. 5-6, pp. 609-624.

Morris, T., Gardner, H. and Anand, N. (2012), "Structuring Consulting Firms", in Kipping, M. and Clark, T. (Eds), The Oxford Handbook of Management Consulting, Oxford University Press, pp. 285-302.

Nikolova, N. and Devinney, T. (2012), "The Nature of client-consultant interaction: A critical review", in Kipping, M. and Clark, T. (Eds), The Oxford Handbook of Management Consulting, Oxford University Press, pp. 389-409.

Nikolova, N., Möllering, G. and Reihlen, M. (2015), “Trusting as a 'leap of faith': Trust-building practices in client-consultant relationships", Scandinavian Journal of Management, Vol. 31 No. 2, pp.232-245.

Nikolova, N., Reihlen, M. and Schlapfner, J. (2009), "Client-consultant interaction: Capturing social practices of professional service production", Scandinavian Journal of Management, Vol. 25, pp. 289298.

O'Mahoney, J. and Markham, C. (2013), Management Consultancy (2nd Edition), Oxford University Press.

Pettigrew, A. M., (2012), "Context and action in the transformation of the firm: A reprise". Journal of Management Studies, 49(7), 1304-1328.

Pettigrew, A.M. \& Whipp, R., (1991), Managing change for competitive success, Oxford: Blackwell Publishers Ltd.

Retna, K.S., (2015), "Consultants and their views on changing the mental models of clients", Journal of Change Management, Vol. 16 No. 3, pp. 184-200.

Saam, N.J. (2012), "Economics Approaches to Management Consulting", in Kipping, M. and Clark, T. (Eds), The Oxford Handbook of Management Consulting, Oxford University Press, pp. 207-224.

Schein, E. (1997), "The concept of "client" from a process consultation perspective: A guide for change agents", Journal of Organisational Change Management, Vol. 10 No. 3, pp. 202-216.

Seo, M-G, Putnam, LL. and Bartunek, J.M. (2004), "Dualities and tensions of planned organisational change" in Poole M.S. and Van de Ven, A.H. Handbook of organisational change and innovation, Oxford University Press, pp. 73-106.

Solomonson, W.L. (2012), "Trust and the client-consultant relationship", Performance Improvement Journal, Vol. 25 No. 3, pp. 53-80.

Sturdy, A. (1997), "The consultancy process - An insecure business", Journal of Management Studies, Vol. 34 No. 3, pp. 389-413. 
Sturdy, A. (2011), “Consultancy's consequences? A critical assessment of management consultancy's impact on management", British Journal of Management, Vol. 22 No. 3, pp. 517-530.

Sturdy, A., Clark, T., Fincham, R. and Handley, K. (2009), "Between innovation and legitimation boundaries and knowledge flow in management consultancy", Organisation, Vol. 16 No. 5, pp. 627653.

Sturdy, A., Schwarz, M. and Spicer, A. (2006), "Guess who's coming to dinner? Structures and uses of liminality in strategic management consultancy", Human Relations, Vol. 59 No. 7, pp929-960.

Sutherland, F. and Smith, A.C.T. (2013), "Leadership for the age of sustainability: A dualities approach to organisational change", in By, R.T. and Burnes, B. (Eds.), Organisational change, leadership and ethics: Leading organisations towards sustainability, London: Routledge, pp. 216-239.

Van Nistelrooij, A., De Caluwe, L. and Schouten, N. (2007), "Management consultants' colourful ways of looking at change: An explorative study under Dutch management consultants", Journal of Change Management, Vol. 17. Nos 3-4, pp. 243-254.

Visscher, K. (2006), "Capturing the competence of management consulting work", Journal of Workplace Learning, Vol. 18 No. 4, pp. 248-260.

Werr, A. and Pemer, F. (2007), "Purchasing management consulting services - From management autonomy to purchasing involvement", Journal of Purchasing and Supply Management, Vol. 13, pp. 98-112.

Werr, A. and Stjernberg, T. (2003), "Exploring management consulting firms as knowledge systems", Organisation Studies, Vol.24 No. 6, pp. 881-908.

Werr, A., Stjernberg, T. and Docherty, P. (1997), "The functions of methods of change in management consulting", Journal of Organisational Change Management, Vol. 10 No. 4, pp. 288-307.

Werr, A. and Styhre, A. (2003), "Management consultants - Friend or foe? Understanding the ambiguous client-consultant relationship", International Studies of Management and Organisation, Vol. 32 No. 4, pp. 43-66.

Whittle, A. (2006), "The paradoxical repertoires of management consultancy", Journal of Organisational Change Management, Vol. 19 No. 4, pp. 424-436.

Whittington, R., Molloy, E., Mayer, M. and Smith, A. (2006), "Practices of strategising/organising: Broadening strategy work and skills", Long Range Planning, Vol. 39 No. 6, pp. 615-629.

Wright, C., Sturdy, A. \& Wylie, N. (2012), "Management innovation through standardisation: Consultants as standardisers of organisational practice", Research Policy, 41, pp. 652-662. 